\title{
FRUITING PHENOLOGY AND CONSUMPTION BY BIRDS IN Ficus calyptroceras (MIQ.) MIQ. (MORACEAE)
}

\author{
RAGUSA-NETTO, J. ${ }^{1}$ \\ Departamento de Ciências Naturais, Universidade Federal do Mato Grosso, C.P. 210, \\ CEP 79600-000, Três Lagoas, MS, Brazil \\ Correspondence to: José Ragusa-Netto, Departamento de Ciências Naturais, Universidade Federal do Mato Grosso, \\ C.P. 210, CEP 79600-000, Três Lagoas, MS, Brazil, e-mail: forpus@ceul.ufms.br \\ Received May 31, 2001 - Accepted July 2, 2001 - Distributed May 31, 2002
}

(With 1 figure)

\begin{abstract}
Figs are a remarkable food resource to frugivores, mainly in periods of general fruit scarcity. Ficus calyptroceras Miq. (Moraceae) is the only fig species in a type of dry forest in western Brazil. In this study I examined the fruiting pattern as well as fig consumption by birds in F. calyptroceras. Although rainfall was highly seasonal, fruiting was aseasonal, since the monthly proportion of fruiting trees ranged from $4 \%$ to $14 \%$ ( $\mathrm{N}=50$ trees). I recorded 22 bird species feeding on figs. In the wet season 20 bird species ate figs, while in the dry season 13 did. Parrots were the most important consumers. This group removed $72 \%$ and $40 \%$ of the figs consumed in the wet and dry seasons, respectively. No bird species increases fig consumption from dry to wet season. However, a group of bird species assumed as seed dispersers largely increases fig consumption from wet to dry season, suggesting the importance of this resource in the period of fruit scarcity. The results of this study points out the remarkable role that $F$. calyptroceras plays to frugivorous birds, in such a dry forest, since its fruits were widely consumed and were available all year round.
\end{abstract}

Key words: frugivory, Ficus, birds, tropical dry forest, western Brazil.

\section{RESUMO}

\section{Fenologia da frutificação e consumo de figos por aves em Ficus calyptroceras Miq. (Moraceae)}

Os frutos de figueiras têm se mostrado relevantes para os frugívoros, especialmente durante a estação seca, quando frutos carnosos tendem a ser escassos. Ficus calyptroceras Miq. (Moraceae) é a única espécie desse gênero presente num tipo de mata decídua do oeste brasileiro. Estudei o padrão de frutificação nessa espécie, bem como o consumo de frutos por aves nas estações chuvosa e seca. Embora a precipitação tenha sido fortemente sazonal, o padrão de frutificação foi assincrônico, pois de $4 \%$ a $14 \%$ das figueiras frutificaram a cada mês ( $\mathrm{N}=50$ árvores). Os figos foram consumidos por 22 espécies de aves, sendo que 20 delas foram registradas explorando esses frutos na estação chuvosa e 13, na estação seca. Os psitacídeos foram os principais consumidores, uma vez que removeram $72 \%$ e $40 \%$ dos figos consumidos nas estações chuvosa e seca, respectivamente. Nenhuma espécie ampliou o consumo de figos na estação chuvosa em relação ao que consumiu na estação seca. No entanto, um grupo de aves com potencial dispersor das sementes elevou substancialmente o consumo de figos da estação úmida para a seca. Os resultados desse estudo sugerem que $F$. calyptroceras desempenha papel relevante nessas matas secas para a comunidade de aves frugívoras, por ser altamente explorado por um grande conjunto de espécies e devido ao padrão assincrônico de frutificação.

Palavras-chave: frugivoria, Ficus, aves, floresta caducifólia, Brasil. 


\section{INTRODUCTION}

In many tropical forests the coexistence of some fig species is common; fig trees occur in high density and produce large crops (Jansen, 1979). Annually, in periods of general fruit scarcity figs have been pointed out as a remarkable resource to frugivores (Leighton \& Leighton, 1983; Terborgh, 1986; Lambert \& Marshall, 1991; Kinnaird et al., 1996; Kannan \& James, 1999).

Features such as a year-round fruiting pattern, a distinctive intra-crown synchrony of fruit ripening, the relatively short intervals between fruiting by individual trees and the ease with which figs can be harvested by a diverse assemblage of frugivores, contribute to the unique role that figs play in frugivore survival (Lambert \& Marshall, 1991).

Although the nutritional quality of figs is low and fruits contain considerable amounts of indigestible fibre (Morrison, 1978; Milton, 1980; Borges, 1993), figs are widely present in the diet of fruit bats (Bonaccorso, 1979; Morrison, 1978), primates (Estrada \& Coates-Estrada, 1984; Milton, 1980; Terborgh, 1986) and birds (Lambert, 1989a; Kinnaird et al., 1996). Particularly, bird assemblages feeding on figs have been recorded as the most diverse among vertebrates (Breitwisch, 1983; Jordano, 1983; Scott \& Martin, 1984; CoatesEstrada \& Estrada, 1986; Lambert, 1989a; Goodman et al., 1997). Birds are also remarkable in their role as fig dispersers (Coates-Estrada \& Estrada, 1986; Lambert, 1989a, b; Kinnaird et al., 1996) or figseed predators (Jansen, 1981; Lambert, 1989b).

In western Brazil, Ficus calyptroceras Miq (Moraceae) is the only fig species in deciduous forests that occurs on calcareous rich soils. F. calyptroceras is abundant and trees commonly bear crops with more than 20,000 figs. In this study I examined the fruiting pattern of a population of $F$. calyptroceras and evaluated fig consumption by birds both in the dry and wet seasons, since studies in the New World tropics have emphasised the importance of fruitresource availability on the spatial and temporal occurrence of frugivorous birds (Skutch, 1967; Karr, 1982; Stiles, 1985; Levey, 1988; Blake \& Loiselle, 1991; Loiselle \& Blake, 1991).

\section{METHODS}

\section{Study site}

This study was carried out in a dry forest $\left(19^{\circ} 01^{\prime} \mathrm{S}\right.$ and $57^{\circ} 41^{\prime} \mathrm{W}$, altitude $\left.\pm 130 \mathrm{~m}\right)$ near the city of Corumbá, Mato Grosso do Sul State. The site is approximately 8,000 ha in area, part of a dry forest belt around Corumbá. This forest is on calcareous rich soil both in flat and hill terrain. Although most of the area is covered by primary forest, there are disturbances caused by logging, resulting in a long clearing in the flat area. Mean annual temperature is $25^{\circ} \mathrm{C}$. Annual rainfall is around $1,000 \mathrm{~mm}$, with $800 \mathrm{~mm}$ falling from October to March (wet season) and $200 \mathrm{~mm}$ from April to September (dry season).

The vegetation is composed of deciduous forest with a canopy of 8-13 m. Species such as Aspidosperma pyrifolium (Apocynaceae), Miracrodruon urundeuva (Anacardiaceae), Tabebuia impetiginosa (Bignoniaceae), Ceiba boliviana (Bombacaceae), Cereus peruvianus (Cactaceae), Anadenanthera colubrina (Leguminoseae-Mimosoideae), and Ficus calyptroceras (Moraceae) are among the commonest species (Ratter et al., 1988).

\section{Field procedures}

I established a $5 \mathrm{~km}$ transect for phenological observation alongside which (10 $\mathrm{m}$ in both sides) 50 individuals of $F$. calyptroceras (DBH $>10 \mathrm{~cm}$ ) were marked with numbered aluminum tags and monitored every two weeks (from July 1999 to June 2000 ) for the presence of figs. The monthly surveys were carried out during two mornings, the first around the $10^{\text {th }}$ day and the second around the $25^{\text {th }}$ day. Fruit abundance was visually estimated using $8 \times 30$ binoculars, and scored on a relative scale from 0 to 4 , ranging from the total absence to a crown full of figs. A monthly index of fig abundance was calculated as $(100 \times$ sum of abundance score)/50. All trees were measured at DBH since the trunk of $F$. calyptroceras, in this sample, is slightly or even not buttressed. I took 30 ripe figs from three different trees to measure their length and diameter with a digital caliper. Seeds from these figs were also counted. 
In each season three large trees $(>50,000$ figs, crop size estimated by visual counts, Chapman et al. [1992]) were observed with the aid of $8 \times$ 30 binoculars for $18 \mathrm{~h}$ (6 h each tree, from 6:00 to $9: 00 \mathrm{~h}$ ) in order to examine ripe fig consumption by birds. The entire fruiting crown of these trees was observed from the ground at a distance of 30$50 \mathrm{~m}$. During the observations I recorded the species and number of individuals entering and exiting the tree as well as time feeding on figs. Whenever possible I recorded the number of figs eaten per minute by the most accessible individual of a species. To estimate fig consumption by a species in each season, the following calculations were made: (number of visits) $\times$ (mean number of birds per visit) $\times$ (mean time of visits) $\times$ (mean number of figs ingested per minute). I assumed as potential seed dispersers those bird species that ingested whole figs and flew away from the tree after foraging, instead of resting in the tree crown. Parrots were assumed as seed predators (Jansen, 1981) since they possess a bill morphology adapted for seed crushing.

\section{RESULTS}

The mean ( $\pm \mathrm{sd}$ ) diameter of figs was $14.4 \pm$ $1.2 \mathrm{~mm}$, and mean length was $13.5 \pm 1.0 \mathrm{~mm}$. Figs were reddish in colour when ripe. The mean number of seeds per fruit was $545 \pm 117$. The $\mathrm{DBH}$ of trees ranged from 22 to $120 \mathrm{~cm}$. Mean DBH was $53.7 \pm$ $21.9 \mathrm{~cm}$. The initial appearance of syconia (hereafter fruit initiation) as well as ripening figs were recorded during all months in the sampled population. The time-lapse from fruit initiation to fruit ripening ranged from 4 to 9 weeks (although 9 weeks was exceptional). Fruit crops were quickly depleted during the ripening period. Ripe crops persisted less than two weeks and in some cases only for five days (four trees monitored for the observation of fig consumption by birds). In the twelve months of observations, eight trees produced no figs, 28 bore figs once and 14 bore figs twice. Among the trees that failed to fruit, only one was a large tree $(\mathrm{DBH}>60 \mathrm{~cm})$. On the other hand, all the trees that produced fruits twice were among the larger ones (DBH between 60-120 cm).

Rainfall was $817 \mathrm{~mm}$ in the study period. In the dry season rainfall was only $168 \mathrm{~mm}$ while in the wet season it was $649 \mathrm{~mm}$ (Fig. 1). The monthly number of trees bearing ripe figs ranged from two (September and December 1999) to seven trees
(January 2000, Fig. 1). The percentage of trees bearing ripe figs in the dry and wet seasons was similar (48\% and 52\%, respectively). Although the number of trees bearing ripe figs was higher in some months, in most months $6 \%-10 \%$ of the trees were fruiting, indicating absence of a specific fruiting period. The two major reductions in the number of fruiting trees were recorded in September (end of the dry season) and December (middle wet season; Fig. 1). These were among the driest and wettest months, respectively. Fig abundance followed a pattern like the monthly proportion of trees bearing ripe figs; it was lowest in September 1999. However, the largest crops occurred in August, January, and March (Fig. 1). A total of 22 bird species were recorded feeding on figs. Most were Emberizidae (5 species), followed by Tyrannidae and Psittacidae (both 4), Muscicapidae (3), Corvidae (2), Cotingidae (1), Trogonidae (1), Momotidae (1), and Ramphastidae (1; Table 1). Parrots were the major consumers both in the dry and wet seasons. In both seasons, the parakeet Pyrrhura molinae consumed most figs, in similar amounts (Table 1).

In the wet season up to 20 species were observed feeding on figs, eating an estimated 83,000 figs. However, eight species showed low consumption - each consumed less than $1 \%$ of the total. On the other hand, parrots ate $72 \%$ of all figs removed (Table 1). Aratinga leucophthalmus, Brotogeris chiriri, and Pionus maximiliani were recorded feeding on figs only in this season. Thraupis sayaca consumed $16 \%$ of the figs, whereas the consumption of potential dispersers such as Pitangus sulfuratus, Cyanocorax cyanomelas, Trogon curucui, Psarocolius decumanus, and Ramphastos toco was approximately $10 \%$, when grouped.

In the dry season figs were consumed $(85,000$ figs) by 13 species. Five of them consumed less than $1 \%$ of the total. Pyrrhura molinae was the only parakeet recorded feeding on figs and the most important consumer as well $(40 \%)$. Brotogeris chiriri was observed flying over focal trees, but was not recorded feeding on figs. Aratinga leucophthalmus and Pionus maximiliani apparently were absent from the area. Thraupis sayaca increased its consumption to $27 \%$ of the figs taken by birds. The consumption of potential dispersers (Pitangus sulfuratus, Turdus amaurochalinus, Cyanocorax cyanomelas, Trogon curucui, Psarocolius decumanus, and Ramphastos toco) was $33 \%$ of the figs removed by birds, when grouped. 

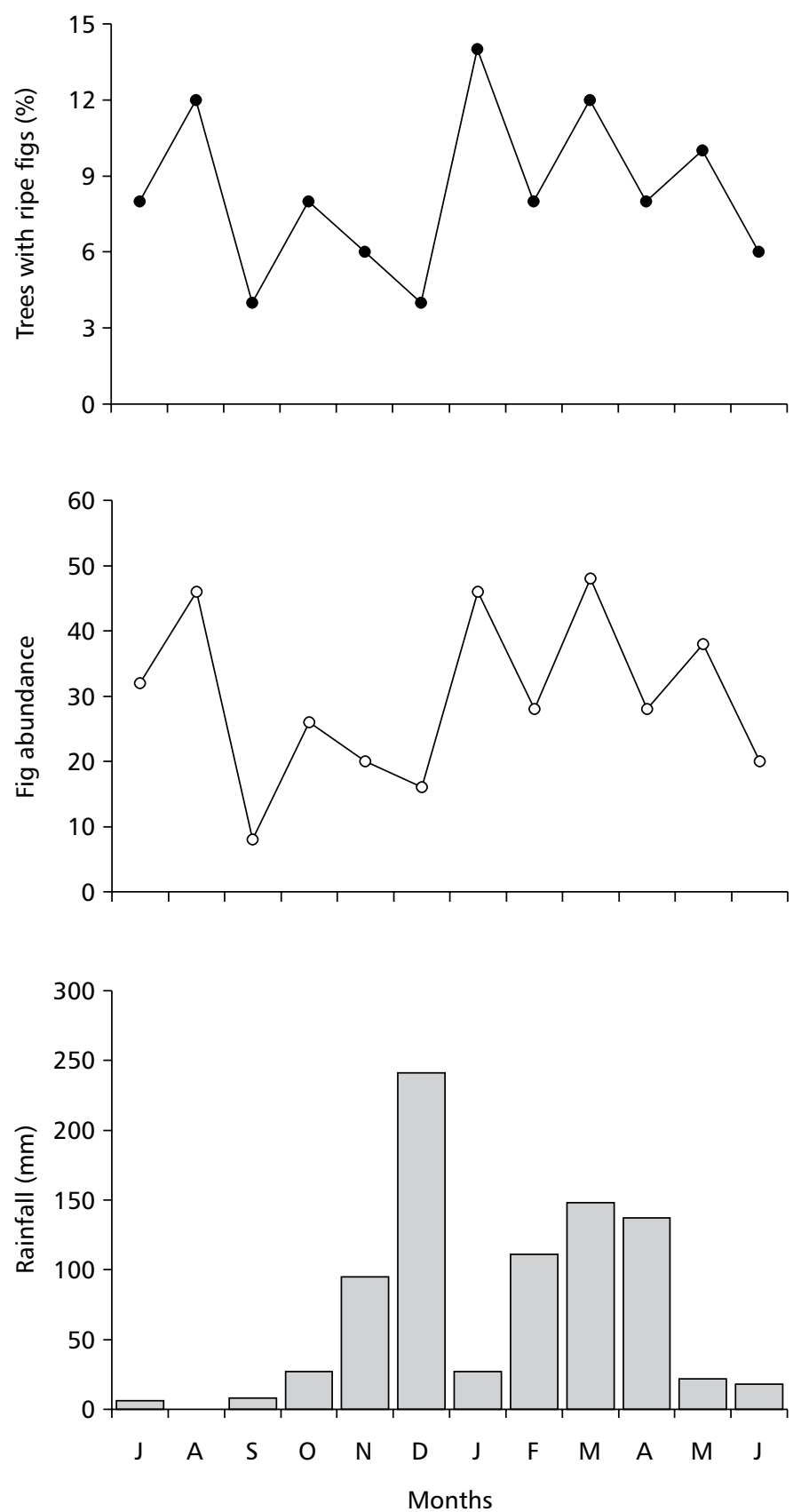

Fig. 1 - From top to bottom: monthly proportion of trees bearing ripe figs, fig abundance, and monthly rainfall $(\mathrm{N}=50$ trees, from July 1999 to June 2000). 
TABLE 1

Bird species* observed feeding on ripe figs of Ficus calyptroceras in the dry and wet seasons (- denotes the absence of the species; the sample size in parentheses).

\begin{tabular}{|c|c|c|c|c|c|c|c|}
\hline \multirow[t]{2}{*}{ Taxa } & \multirow{2}{*}{$\begin{array}{c}\text { Fruits per min } \\
(\text { mean } \pm \text { sd })\end{array}$} & \multicolumn{2}{|c|}{$\begin{array}{l}\text { Visits per } \\
\text { hour }\end{array}$} & \multicolumn{2}{|c|}{$\begin{array}{l}\text { Visit length }(\mathrm{min}) \\
\quad(\text { mean } \pm \text { sd })\end{array}$} & \multicolumn{2}{|c|}{$\begin{array}{l}\text { Fruits removed } \\
\qquad(\%)\end{array}$} \\
\hline & & Dry & Wet & Dry & Wet & Dry & Wet \\
\hline Psitacidae & & & & & & & \\
\hline Pyrrhura molinae & $2.8 \pm 1.0(30)$ & 6.80 & 5.60 & $17.2 \pm 8.1(94)$ & $14.9 \pm 5.7(113)$ & 40 & 38 \\
\hline Brotogeris chiriri & $2.5 \pm 1.3(30)$ & - & 1.90 & - & $43.3 \pm 19.6(37)$ & - & 28 \\
\hline $\begin{array}{l}\text { Aratinga } \\
\text { leucophthalmus }\end{array}$ & $1.3 \pm 0.8(20)$ & - & 1.60 & - & $24.6 \pm 6.2(32)$ & - & 3 \\
\hline Pionus maximiliani & $1.0 \pm 0.4(20)$ & - & 1.80 & - & $38.2 \pm 2.7(16)$ & - & 3 \\
\hline Ramphastidae & & & & & & & \\
\hline Ramphastos toco & $3.0 \pm 1.1(15)$ & 0.54 & 0.50 & $11.8 \pm 2.9(12)$ & $13.3 \pm 8.1(10)$ & 1.0 & 0.6 \\
\hline Trogonidae & & & & & & & \\
\hline Trogon ситисиi & $1.3 \pm 0.5(20)$ & 4.90 & 2.00 & $8.9 \pm 4.2(108)$ & $5.2 \pm 1.8(40)$ & 3.3 & 0.4 \\
\hline Tyrannidae & & & & & & & \\
\hline Pitangus sulfuratus & $1.0 \pm 0.6(30)$ & 5.90 & 3.20 & $1.5 \pm 0.8(130)$ & $1.1 \pm 0.4(149)$ & 12 & 6.5 \\
\hline Muscicapidae & & & & & & & \\
\hline $\begin{array}{l}\text { Turdus } \\
\text { amaurochalinus }\end{array}$ & $2.0 \pm 0.4(30)$ & 4.00 & 1.30 & $3.0 \pm 1.2(138)$ & $3.1 \pm 0.4(82)$ & 11 & 0.3 \\
\hline Corvidae & & & & & & & \\
\hline $\begin{array}{l}\text { Cyanocorax } \\
\text { cyanomelas }\end{array}$ & $3.0 \pm 0.7(20)$ & 2.00 & 1.10 & $8.4 \pm 2.7(59)$ & $3.9 \pm 0.4(22)$ & 4.7 & 0.5 \\
\hline Emberizidae & & & & & & & \\
\hline $\begin{array}{l}\text { Psarocolius } \\
\text { decumanus }\end{array}$ & $2.0 \pm 0.9(30)$ & 2.90 & 3.40 & $7.3 \pm 0.8(53)$ & $4.3 \pm 1.2(68)$ & 1.0 & 0.8 \\
\hline Icterus cayanensis & $1.5 \pm 0.4(13)$ & - & 1.3 & - & $10.1 \pm 2.5(26)$ & - & 1.2 \\
\hline Thraupis sayaca & $1.4 \pm 0.6(30)$ & 5.40 & 4.30 & $8.6 \pm 3.4(119)$ & $6.1 \pm 3.6(107)$ & 27 & 16 \\
\hline
\end{tabular}

* Species whose consumption was less than $1 \%$ of the figs removed: Momotus momota (d), Tityra cayana (w), Megarynchus pitangua (w,d), Myiodynastes maculatus (w), Tyrannus melancholicus (w), Turdus rufiventris (w), Platycichla flavipes (d), Cyanocorax chrysops (w,d), Cacicus solitarius (w,d), and Icterus icterus (w). (w: figs consumed in the wet season; d: consumed in the dry season.) 
In the dry season Pitangus sulfuratus, Turdus amaurochalinus, Cyanocorax cyanomelas, and Trogon curucui, besides Thraupis sayaca, greatly increased fig consumption in relation to the wet season (Table 1). No species observed feeding on figs in both seasons increased consumption from the dry to the wet season.

Most bird species with consumption higher than $1 \%$ (9 of 12, Table 1) visited fig trees in flocks. Pyrrhura molinae and Brotogeris chiriri sometimes visited fig trees in flocks larger than 10 birds. On the other hand, most of the time such species as Trogon curucui, Turdus amaurochalinus and Pitangus sulfuratus visited the trees alone. However, simultaneous visits by conspecifics occurred, since birds approached the trees from different directions.

Parrots usually mandibulated figs with the aid of their feet, dropping pieces of the fig with seeds attached under the crown. Species such as Thraupis sayaca and Icterus cayanensis also mandibulated figs or pieces of the fruit, dropping pieces of the fig with seeds attached under the crown.

Six species (Pitangus sulfuratus, Cyanocorax cyanomelas, Trogon curucui, Turdus amaurochalinus, Ramphastos toco and Psarocolius decumanus) ingested figs whole and their visits lasted less than $10 \mathrm{~min}$. (except for $R$. toco). Due to this pattern of visits, they potentially contributed to seed dispersal.

\section{DISCUSSION}

Although an increase or a reduction in the number of fruiting trees was observed in some months, the fruiting pattern in Ficus calyptroceras was clearly asynchronous. Trees initiated fruit crops as well as bore ripe figs in all months of the year, as did other Ficus species studied elsewhere in the tropics (Foster, 1982; Milton et al., 1982; Leighton \& Leighton, 1983; van Shaik, 1986; Corlett, 1987; Windsor et al., 1989). In spite of the fact that $F$. calyptroceras occurs in a deciduous forest where the dry season is severe and heavy rainfall is concentrated in few months, the proportion of trees bearing figs was similar in both seasons. The same trend was verified for fig abundance. Thus, crop size was not influenced by rainfall either. Moreover, trees bore fruits at intervals shorter than a year and in some cases shorter than six months, which presumably influenced fruiting asynchrony (Milton et al., 1982).

Milton et al. (1982) suggested that the major advantage of an asynchronous fruiting pattern in Ficus is to increase seed success through saturation of the environment with seeds as frequently and in as many months of the year as possible. As a colonizing species, this strategy can enhance the chances of seeds to arrive to suitable germination sites such as light gaps, which are limited and unpredictable in space and time. Each tree has its own particular fruiting interval regardless of climate, but is influenced by the level of accumulated resources required to initiate a fruit crop. Thus, fruiting at different times of the year must be related to increasing each tree's chance of success with respect to seed set, pollen dispersal (since each fig species is pollinated by a specific short-lived wasp; Ramirez, 1970), and seed dispersal during its total lifetime

The bird assemblage observed feeding on figs in this study was among the richest recorded consuming figs in the neotropics (Jansen, 1979; Jordano, 1983; Coates-Estrada \& Estrada, 1986). Also, both small (T. sayaca, $\pm 30 \mathrm{~g}$ ) and large ( $R$. toco, $\pm 500 \mathrm{~g})$ birds were among the consumers. As pointed out by Jordano (1983), the presence of small seeds and fruits, which birds may mandibulate and/or peck in order to consume the pulp, may account for the rich assemblage noted exploiting figs (Need Portuguese version).

Parrots consumed most figs of F. calyptroceras, as recorded for $F$. cotinifolia in a dry forest in Costa Rica (Jordano, 1983). Nevertheless, in a wet forest in southern Mexico, parrots were not among consumers (Coates-Estrada \& Estrada, 1986). Although only few studies were carried out on fig consumption by birds in the neotropics, the intense fig consumption by parrots in dry forests (Jordano, 1983; this study) suggests that figs may be a major item in the diet of parrots that live in highly seasonal forests.

Parrots are considered seed predators, as they usually crack and/or digest all the fig seeds ingested (Jansen, 1981). Thus, for parrots, the nutritional value of figs was presumably increased by the nutrients in the seeds. Apparently, F. calyptroceras is particularly important for Pyrrhura molinae. This parakeet occurs all year round in this dry forest 
and was observed feeding on figs in all months of the year. F. calyptroceras is the major component of its diet, mainly in the dry season (figs corresponded to more than $80 \%$ of the feeding records; Ragusa-Netto, unpublished obs.).

Although some seeds may pass through the parrots' digestive tract intact (Jansen, 1981), some intact seeds were very likely defecated under the crown, since their visits were long. In spite of the fact that most figs were consumed by parrots, their contribution to fig dispersal was presumably minimal or none. Other species (e.g. Thraupis sayaca, Icterus cayanensis, Cacicus solitarius) mandibulated figs, usually dropping pieces of fruits (with seeds attached) under the crown. Those species remained for 8-12 min. at the fig crown. This pattern of consumption probably decreased the contribution of these species to seed dispersal (Coates-Estrada \& Estrada, 1986).

Species such as Pitangus sulfuratus, Trogon curucui, Turdus amaurochalinus, Cyanocorax cyanomelas, Psarocolius decumanus, and Ramphastos toco showed a pattern of consumption, which suggested seed dispersal potential. All of them ingested figs whole and left the trees soon after eating figs. Moreover, most of these species foraged for figs in short visits, which reduces the probability of seed defecation or regurgitation under the crown (Coates-Estrada \& Estrada, 1986).

At the study site, other fleshy fruits were almost absent during the long dry season (pers. obs.). Thus, F. calyptroceras, the only fig species in this deciduous forest, may be important for frugivores. The importance of figs as a resource for frugivores in tropical forests has been emphasised in many studies (Leighton \& Leighton, 1983; Terborgh, 1986; Lambert \& Marshall, 1991; Kinnaird et al., 1996; Kannan \& James, 1999). Lambert \& Marshall (1991) pointed out that the combination of attributes such as large crop size, relative numerical abundance and availability even in periods of general fruit scarcity, makes Ficus a unique and extremely important resource to frugivores. Also, figs are energy-rich foods and have higher caloric values than non fig-fruits, besides the fact that they include some protein (Wrangham et al., 1993). Moreover, most figs are succulent, soft, easily harvested and ingested whole or piecemeal. Due to their short crop persistence and synchronous maturation within a tree, a high proportion of fruits are available daily during the ripening period (Lambert \& Marshall, 1991). These features, found in $F$. calyptroceras, presumably influenced the enhancement in fig consumption by several bird species in the dry season. As mentioned above, in the dry season other fleshy fruits were scarce and the intense leaf loss by most trees presumably reduced arthropod availability included in the diet of most birds (Ridgely \& Tudor, 1989, 1994; Sick, 1997; pers. obs.) were recorded feeding on figs. Thus, apparently, F. calyptroceras plays a major role in the persistence of frugivores during the harsh dry season in such deciduous forests of western Brazil.

Acknowledgments - I am grateful to PROPP (UFMS) for financial support and Vanda Lúcia Ferreira for field assistance. An anonymous reviewer and Regina Baruki Fonseca improved the English.

\section{REFERENCES}

BLAKE, J. G. \& LOISELLE, B. A., 1991, Variation in resource abundance affects capture rates of birds in three lowland habitats in Costa Rica. Auk, 108: 114-130.

BORGES, R., 1993, Figs, malabar giant squirrels, and fruit shortage within two tropical Indian forests. Biotropica, 25: $183-190$.

BONACCORSO, F. J., 1979, Foraging and reproductive ecology in a Panamanian bat community. Bull. Fla. St. Mus. Biol. Sci., 24: 359-408.

BREITWISCH, R., 1983, Frugivores at a fruiting Ficus vine in southern Cameroon tropical rain forest. Biotropica, 15: 125-128.

CHAPMAN, C. A., HUNT, K. \& GEBO, D., 1992, Estimators of fruit abundance of tropical trees. Biotropica, 24: 527-531.

COATES-ESTRADA, R. \& ESTRADA, A., 1986, Fruiting and frugivores at a strangler fig in the tropical rain forest of Los Tuxtlas, Mexico. J. Trop. Ecol., 2: 349-357.

CORLETT, R. T., 1987, The phenology of Ficus fistulosa in Singapore. Biotropica, 19: 122-124.

ESTRADA, A. \& COATES-ESTRADA, R., 1984, Fruit-eating and seed dispersal by howling monkeys (Alouatta palliata) in the tropical rain forest of Los Tuxtlas, Mexico. Amer. J. Primatol., 6: 77-91.

FOSTER, R. B., 1982, The seasonal rhythms of fruitfall on Barro Colorado Island. In: E. G. Leigh, A. S. Rand \& Windsor (eds.), The ecology of a tropical forest. Smithson. Inst. Press, Washington, D.C.

GOODMAN, S. M., GANZHORN, J. U. \& WILMÉ, L., 1997, Observations at a Ficus tree in Malagasy humid forest. Biotropica, 29: 480-488.

JANSEN, D., 1979, How to be a fig. A. Rev. Ecol. Syst., 10: 13-51. 
JANSEN, D., 1981, Ficus ovalis seed predation by Orange Parakeet (Brotogeris jugularis) in Costa Rica. Auk, 98: 841-844.

JORDANO, P., 1983, Fig-seed predation and dispersal by birds. Biotropica, 15: 38-41.

KANNAN, R. \& JAMES, D. A., 1999, Fruiting phenology and the conservation of the Great Pied Hornbill (Buceros bicornis) in Western Ghats of Southern India. Biotropica, 31: $167-177$.

KARR, J. R., 1982, Population variability and extinction in the avifauna of a tropical land bridge island. Ecology, 63: 1975-1978.

KINNAIRD, M. F., O'BRIEN, T. G. \& SURYADI, S., 1996 , Population fluctuation in Sulawesi Red-Knobbed Hornbills: tracking figs in space and time. Auk, 113: 431-440.

LAMBERT, F., 1989a, Fig-eating by birds in a Malaysian lowland rain forest. J. Trop. Ecol., 5: 401-412.

LAMBERT, F., 1989b, Pigeons as seed predators and dispersers of figs in a Malaysian lowland forest. Ibis, 131: 521-527.

LAMBERT, F. \& MARSHAL, A. G., 1991, Keystone characteristics of bird-dispersed Ficus in a Malaysian lowland rain forest. J. Ecol., 79: 793-809.

LEIGHTON, M. \& LEIGHTON, D., 1983, Vertebrate responses to fruiting seasonality within a Bornean rain forest. In: S. L. Sutton, T. C. Whitmore \& A. C. Chadwick (eds.), Tropical rain forest: ecology and management. Blackwell Scientific Publications, Oxford, England.

LEVEY, D. J., 1988, Spatial and temporal variation in Costa Rican fruit and fruit-eating bird abundance. Ecol. Monog. 58: 251-269.

LOISELLE, B. A. \& BLAKE, J. B., 1993, Spatial distribution of understory fruit-eating birds and fruiting plants in a Neotropical lowland wet forest. Vegetatio, 107/108: 177190.

MILTON, K., 1980, The foraging strategy of howler monkeys: a study in primate economics. Columbia Univ. Press, New York

MILTON, K., WINDSOR, D. M., MORRISON, D. W. \& ESTRIBI, M. A., 1982, Fruiting phenologies of two tropical Ficus species. Ecology, 63: 752-762.
MORRISON, D. W., 1978, Foraging ecology and energetics of the frugivorous bat Artibeus jamaicensis. Ecology, 59: 716-723.

RAMIREZ, W. B., 1970, Host specificity of fig wasps (Agonidae). Evolution, 24: 680-691.

RATTER, J. A., POTT, A., POTT, V. J., CUNHA, C. N. \& HARIDASAN, M., 1988, Observation on wood vegetation types in the Pantanal at Corumbá, Brazil. N. RBG. Edinb., 3: 503-525.

RIDGELY, R. S. \& TUDOR, G., 1989, The birds of South America. 1ำ vol., The Oscine Passerines. Oxford Univ. Press., Oxford.

RIDGELY, R. S. \& TUDOR, G., 1994, The birds of South America. The Suboscine Passerines. 2o vol., Oxford Univ. Press., Oxford.

SCOTT, P. E. \& MARTIN, R. F., 1984, Avian consumers of Bursera, Ficus, and Ehretia fruit in Yucatán. Biotropica, 16: 319-323.

SICK, H., 1997, Ornitologia brasileira. Nova Fronteira, Rio de Janeiro, 912p.

SKUTCH, A., 1967, Life histories of Central American highland birds. Nuttall Ornithol. Club 7.

STILES, F. G., 1985, On the role of birds in the dynamics of neotropical forests. pp. 45-59. In: A. W. Diamond \& Lovejoy, T. E. (eds.), International Council for Bird Preservation, Tech Publ. 4.

TERBORGH, J., 1986, Keystone plant resources in the tropical forest. In: M. Soulé (ed.), Conservation biology. Sinauer, Sunderland, Massachussets.

VAN SCHAIK, C. P., 1986, Phenological changes in a Sumatran rain forest. J. Trop. Ecol., 2: 327-347.

WINDSOR, D. M., MORRISON, D. W., ESTRIBI, M. A. \& DE LEON, B., 1989, Phenology of fruit and leaf production by strangler figs on Barro Colorado Island, Panama. Experientia, 45: 647-653.

WRANGHAM, R. M., CONKLIN, N. L., ETOT, G., OBUS, J., HUNT, K. D., HAUSER, M. D. \& CLARK, A. P., 1993, The value of figs to chimpanzees. Int. J. Primatol., 14: 243-255. 